\title{
Jakub Greloff \\ Przyszłość demokracji. Encyklika \\ Centesimus annus po 25 latach.
}

\section{Sprawozdanie z konferencji naukowej, Uniwersytet Warszawski, 24 listopada 2016 r.}

W dniu 24 listopada 2016 r. w Sali Balowej Pałacu Tyszkiewiczów-Potockich odbyła się konferencja naukowa zatytułowana „Przyszłość demokracji. Encyklika Centesimus annus po 25 latach”. Organizatorami konferencji byli uczeni z Instytutu Politologii UKSW i z Instytutu Stosowanych Nauk Społecznych UW.

Konferencję wpisano w obchody dwusetlecia Uniwersytetu Warszawskiego, których założeniem jest pokazanie Uniwersytetu jako miejsca, w którym kształtują się nowe idee i postawy, w którym rodzą się autentyczne wartości; jako miejsca, w którym spotykają się nieprzeciętne indywidualności, ludzie wybitni w swoich dziedzinach, oryginalni i niestandardowi; wreszcie, jako miejsca, w którym przekraczane są granice poszczególnych dyscyplin i w którym różnorodne nauki wnoszą wspólny wkład w lepsze rozumienie świata.

Konferencję poświęcono dziedzictwu Jana Pawła II, a wzięli w niej udział zarówno jego apologeci, jak i krytycy. Organizatorzy nakreślili na wstępie kontekst historyczny w jakim powstawała Encyklika. Upadek komunizmu w Europie Wschodniej, pierwsze wolne wybory, powstanie nowych państw, wprowadzenie gospodarki wolnorynkowej i dynamiczne zmiany kulturowe.

Celem konferencji była refleksja i dyskusja nad konsekwencjami, ale i obecnymi możliwościami jakie przynosi nauczanie społeczne Jana Pawła II. Spotkanie zgromadziło kilkudziesięciu uczestników, wśród których znaleźli się przedstawiciele uczelni, ośrodków naukowych i instytucji państwowych.

Konferencję otworzyli ks. prof. Piotr Mazurkiewicz, prof. Wojciech Pawlik i dr Maciej Zięba OP. Już na wstępie uczeni wskazali na błędną antropologię jako źródło obecnych kryzysów 
demokracji. Centesimus annus daje pełny opis fundamentów antropologii, wskazuje na pojęcie osoby jako samodzielnego podmiotu decyzji moralnych, który podejmując je, tworzy porządek społeczny. Przyjęcie błędnej antropologii, skutkuje deformacją prawa, które określa zakres wolności człowieka. Chrześcijańska koncepcja osoby, podmiotowość jednostki, umożliwiają natomiast nakreślenie należytej wizji społeczeństwa.

Pierwszą sesję pt. „Demokracja i religia” prowadził prof. Wojciech Pawlik. W swym wystąpieniu prof. Rafał Chwedoruk zwrócił uwagę na pewien paradoks: demokracja najbardziej ziściła się w państwach nordyckich, z których część to państwa wyznaniowe. Jego zdaniem, trudno wyobrazić sobie również polską drogę do demokracji bez katolicyzmu i chrześcijaństwa. Profesor Stanisław Mocek, zwrócił uwagę, że dziś głównym zagrożeniem dla demokracji nie muszą być systemy totalitarne, może być ona sama. Marketing polityczny, pełni już nie tylko rolę metody komunikowania, urósł do rangi strategii działania politycznego. Doktor Maciej Zięba OP przeprowadził ambitny wywód, w którym kluczowe założenia encykliki Centesimus annus zestawił z postulatami wiodących myślicieli politycznych i teoretyków polityki. Od warunków istnienia demokracji R. A. Dahla, przez paradoks E.-W. Böckenförde, tezę o niesamowystarczalności demokracji liberalnych F. Fukuyama’y, przez dylematy J.-F. Lyotarda, J. Baudrillarda, R. Rorty’ego, Z. Baumana, G. Vattimo, aż po fenomen pojęcia post-truth („post-prawda”) - ogłoszonego przez redaktorów Oxford Dictionaries „Słowem Roku 2016”.

Drugą sesję pt. „Demokratyczne państwo prawa” prowadził prof. Jan Grosfeld. Profesor Josef Isensee z Uniwersytetu w Bonn, światowej sławy konstytucjonalista i specjalista z zakresu nauki o państwie, podkreślił, że wybór Jana Pawła II zapoczątkował zmiany prowadzące do załamania się bloku państw komunistycznych. Niemiecki uczony, zreferował wizję demokratycznego państwa prawa zawartą w encyklice Centesimus annus. W swym wystąpieniu m.in. poszukiwał odpowiedzi na pytania: czy demokratyczne państwo prawa zastrzeżone jest tylko dla chrześcijan, którzy to w naturalny sposób potrafią iść za wartościami?; czym jest prawda w demokracji?; czy państwo które wszystkim obywatelom gwarantuje wolność religijną nie opowiada się tym samym za relatywizmem? Profesor postawił tezę, iż prawda dla demokracji nie jest żadnym tematem. Demokracja nie jest ani chrześcijańska, ani niechrześcijańska, ani wierząca, ani niewierząca. Wycofanie się państwa z prób poszukiwania prawdy wynika z europejskiego doświadczenia wojen domowych i religijnych. Źródłem konfliktów były roszczenia do posiadania absolutnej prawdy. Stąd demokracja i nowoczesne państwo opierają się na zasadzie pokojowej egzystencji wszystkich obywateli bez względu na wiarę, wyznanie czy światopogląd. Państwo prawa w wizji Jana Pawła II było projektem zaprowadzenia pokoju we wspólnocie narodów. Uczony zwrócił uwagę, iż relatywizm przyjmowany w tym celu przez państwo nie jest natury światopoglądowej, ale pragmatycznej. 
Państwo prawa powstrzymuje się jedynie od ostatecznych rozstrzygnięć na temat prawdy. Nauczanie Papieża Polaka przynosi tu rozróżnienie pomiędzy prawdą i błędem, odrzuca obecnie rozpowszechnioną modę na „post-prawdę”. Jak podkreślił uczony, demokratyczna zasada większości nie dotyka zasadniczych pytań o prawdę, bowiem większość nie ma zastępować prawdy. Od mniejszości żąda się jedynie by uznała rezultat decyzji większości, ale nie zmusza się jej do przyjęcia obcych poglądów. Dziś państwo żąda jedynie posłuszeństwa zewnętrznego, a nie wewnętrznego, żąda legalności, a nie moralności. Mniejszość nie myli się tylko dlatego, że została przegłosowana. W liberalnym państwie prawnym, chodzi o pozytywne wykorzystanie prawdy w celu rozwoju państwa. Prof. Isensee swoje wystąpienie zakończył stwierdzeniem, że Kościół we współpracy z innymi podmiotami może budować zasoby etyczne państwa prawa. Kościół i Państwo pełnią w swojej odmienności zadania komplementarne. Mogą one odzyskać pojęcie wspólnoty dla społeczeństwa.

Profesor Irena Lipowicz przedstawiła pogląd, że autentyczna demokracja możliwa jest jedynie w państwie prawnym uznającym godność człowieka. Jej zdaniem uścisk państwa jest dla Kościoła śmiertelny. Stąd teza, że Kościół i Państwo jeszcze nigdy nie były tak blisko, powinno wzbudzać jedynie niepokój o dobro Kościoła. Ktoś kto traci dystans, traci prawo krytyki, a na końcu traci wolność. Przykładem państwa, w którym taki negatywny proces miał miejsce, są Niemcy. Rozbudowana działalność Kościoła niemieckiego w obszarze charytatywnym, przyniosła mu państwowe subsydia, ale jednocześnie zawęziła spectrum oddziaływania. Zasadne jest tu pytanie o pozostanie w wierności zasadniczej misji chrześcijaństwa. Profesor Jacek Kurczewski zaznaczył potrzebę rozróżnienia pomiędzy określeniami: demokracją pod rządami prawa, a demokratycznym państwem prawa. Pierwszeństwo należy przyznać temu pierwszemu.

Trzecią sesję pt. „Demokracja i gospodarka” prowadziła prof. Aneta Gawkowska. Profesor Aniela Dylus poruszyła zagadnienia: współzależności demokracji i wolnego rynku, kondycji demokracji w kontekście przemian gospodarczych, a także możliwych scenariuszy rozwoju sytuacji. Jako zasadnicze czynniki decydujące o kondycji demokracji Profesor wskazała: utratę prymatu polityki nad gospodarką, marginalizację pracy, prekariat, kryzys związków zawodowych, światowy kryzys 2008+, rozwierające się nożyce nierówności. Profesor Tomasz Dołęgowski zwrócił uwagę, na kontrast pomiędzy zbiorowym poczuciem dumy z Jana Pawła II, a nikłą znajomością jego nauczania społecznego. Zarysował także związki między ekonomią i etyką, w tym wzajemne relacje etyki, dobra wspólnego i konkurencyjności międzynarodowej. Pan Maciej Witucki, w swym wystąpieniu wskazał rolę jako wywiera na gospodarkę świadomość konsumentów. Społeczna odpowiedzialność biznesu (CSR) jest jego zdaniem zjawiskiem wymuszonym przez konsumentów. Tak zwany „Mordor”, dzielnica Warszawy, w której mieszą się siedziby wielu korporacji, wykształcił prekariat, ale jest wśród 
nich też świadomy prekariat, walczący o swoje prawa. Podkreślił, przy tym, że tworzenie się prekariatu, paradoksalnie nie jest w interesie kapitału. Zdaniem Przedsiębiorcy, to gospodarka kreuje demokrację, przykładem tego procesu są elity w instytucjach państwowych, których przedstawiciele coraz częściej wywodzą się ze spółek o zagranicznym kapitale.

Ostatnią sesję podsumowującą całą konferencję prowadzili prof. Marcin Król i ks. prof. Piotr Mazurkiewicz. Sesja przybrała formułę serii pytań zadawanych przez prof. Króla i odpowiedzi w trybie a vista udzielanych przez prof. Mazurkiewicza. Czy nie jest zadaniem Kościoła piętnowanie kłamstwa w życiu publicznym? Na czym polega przekonanie, że Kościół może wpływać na świat? Gdzie są „świadectwa działania” Kościoła zapowiedziane przez Jana Pawła II? Do kogo adresowane jest papieskie nauczanie tam gdzie padają sformułowania „należy” czy „powinno się”? Profesor Mazurkiewicz na wstępie posłużył się wizją Kościoła jako szpitala polowego zaproponowaną przez papieża Franciszka dla zobrazowania zadania jakie stoi przed Kościołem w obszarze życia publicznego. Zaznaczył przy tym, że są spory polityczne takie jak np. życie, w który Kościół powinien uczestniczyć, i są spory w których nie powinien uczestniczyć. Zauważył, że cała debata publiczna funkcjonuje dziś tak jakby prawda nie istniała. Nauczanie Benedykta XVI nt. relacji państwo - Kościół wyraźnie ukazywało, że gdziekolwiek Kościół wchodzi w zbyt bliskie relacje z władzą, to zawsze traci Kościół, nawet jeśli na krótką metę pewne rozwiązania będą wydawały się korzystne. „Świadectwo działania” Kościoła ukazują przede wszystkim ludzie święci, których radykalizm i postawa pociąga do naśladowania. Nauczanie Jana Pawła II doceniało rolę instytucji dla funkcjonowania społeczeństw, ale pierwszeństwo przyznawało roli kultury. Papież podkreślał potrzebę troski o kulturę, bo to ona wpływa na instytucje. Zdaniem prof. Mazurkiewicza stąd wynika aktualność postulatu powrotu Kościoła do roli mecenasa kultury.

Wymiar kulturowy i narodowy jest obok aktywności gospodarczej tym niezbędnym elementem bez którego nie można zrozumieć człowieka. Nakreślenie kontekstu kultury, poprzez język i historię poszczególnych narodów, może przynieść odpowiedzi na najbardziej fundamentalne pytania o sens osobistej egzystencji. Powyższe założenia zawarte w Centesimus annus wskazują, które zagadnienia należałoby dalej dyskutować, aby wkład, który różne nauki wnoszą w lepsze rozumienie świata, był bardziej kompletny.

Jakub Greloff - politolog, doktorant Katedry Teorii Polityki i Myśli Politycznej Instytutu Politologii UKSW w Warszawie. Zainteresowana badawcze: polityka historyczna, polityka pamięci. W druku jest publikacja będąca naukowym opracowaniem Pamiętników Michała Szymona Karskiego (Warszawa). 